\title{
Regulation of odor gas emission and performance by probiotic Bacillus in livestock industry
}

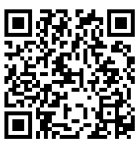

\author{
Young Mu Choi ${ }^{1,2}$ and Yun Jaie Choi ${ }^{1 *}$ \\ ${ }^{1}$ Department of Agricultural Biotechnology, Seoul National University, Republic of Korea \\ ${ }^{2}$ CJ Feed \& Care, CJ Cheil Jedang Republic of Korea
}

Submission: November 14, 2019; Published: November 27, 2019

*Corresponding author: Choi Jaie Yun, Department of Agricultural Biotechnology, Seoul National University, Republic of Korea

\begin{abstract}
Livestock operations have shifted from small farms to industrial facilities. Industrialized farms have benefits with improved the efficiency of animal management however there are problems with these operations, such as infectious disease and waste disposal. In the case of waste disposal, especially odors such as ammonia ( $\mathrm{NH} 3$ ) and hydrogen sulfide (H2S) are problematic on farms. $\mathrm{NH} 3$ and $\mathrm{H} 2 \mathrm{~S}$ emissions can have severe negative effects on farm workers, such as chronic or acute pulmonary disorders, as well as on domestic animals like swine and poultry.

Probiotics are a potential solution for this critical problem. Bacillus-based probiotics complex are generally recognized as useful microorganism to decrease the malodor and enhance the growth performance in livestock. Various studies of dietary supplementation with Bacillus have been conducted on monogastric animals. The dietary supplementation of Bacillus spp. showed several beneficial effects in swine as follows; the reduction of noxious gases ( $\mathrm{NH} 3, \mathrm{H} 2 \mathrm{~S}$ and mercaptan) emission, and the improvement of growth performance parameters such as average daily gain, average daily feed intake and feed conversion ratio. It has been reported that feed supplementation with Bacillus spp. was definitely effective to improve the growth performance and egg production quality in chickens.

Moreover, NH3 and H2S emissions from poultry manure were dramatically decreased after dietary Bacillus spp. supplementation. Some authors have suggested that the beneficial effects of Bacillus supplementation may be boosted by the addition of other probiotics, such as Lactobacillus spp. However, probiotics have a disadvantage as feed additives, namely the inconsistency in results caused by variation in dietary compositions, dose levels, strains, and environmental factors. Additional studies of complex probiotics are needed to find appropriate combinations of microbial sources, that satisfy both odor reduction and growth performance requirements in monogastric animals.
\end{abstract}

Keywords: Odor; Gas emission; Bacillus; Ammonia; Hydrogen sulfide; livestock

Abbreviations: ADG: Average Daily Gain; ADFI: Average Daily Feed Intake; FCR: Feed Conversion Ratio; DFM: Direct Fed Microbial; DM: Dry matter; CP: Crude Protein; EE: Ether Extract; CF: Crude Fiber; GE: Gross Energy; ME: Metabolic Energy; PKM: Palm Kernel Meal

\section{Introduction}

Livestock operations have transitioned over time from small farms to industrial facilities. Industrialized farms have improved the efficiency of animal management. However, there are problems with these large-scale operations, such as infectious disease and waste disposal [1]. Waste disposal can cause environmental issues, including soil erosion and the production of global greenhouse gases and air pollutants $[2,3]$.

In terms of air pollutants, various emissions such as ammonia $\left(\mathrm{NH}_{3}\right)$, hydrogen sulfide $\left(\mathrm{H}_{2} \mathrm{~S}\right)$, methane $\left(\mathrm{CH}_{4}\right)$, nitrous oxide $\left(\mathrm{N}_{2} \mathrm{O}\right)$, volatile organic compounds (VOCs), and other odors are released from livestock production facilities [4]. These emissions are not only a nuisance to people living in nearby residential areas [5] but can also result in health problems for farm workers. Ammonia and $\mathrm{H}_{2} \mathrm{~S}$ have shown critical negative effects on farm workers, including chronic or acute pulmonary disorders, as well as on domestic animals like swine and poultry.

Ammonia is generated from livestock barns, open feedlots, and manure storage facilities on farms, as well as during manure handling, treatment, and spreading. Ammonia dissolves readily in water (e.g., swine urine and drinking water) where it ionizes to form an ammonium ion. The atmospheric pressure and temperature affect ammonia solubility in water from dissolved or suspended materials [6]. On the other hand, ammonia produced in poultry facilities is created by urea and uric acid degradation [7].

Another source of odor in livestock production is $\mathrm{H}_{2} \mathrm{~S}$, which has been recognized as harmful to humans, and animals in deeppit production systems $[8,9]$. Hydrogen sulfide is formed under anaerobic conditions by bacteria reducing sulfate to sulfide; 
sulfide then combines with hydrogen ions to form hydrogen sulfide [10]. Pigs are affected by different levels of hydrogen sulfide. Severe distress, eye irritation, and drooling can be caused by concentrations of $100 \mathrm{ppm}$. Pigs exposed to $250 \mathrm{ppm}$ of $\mathrm{H}_{2} \mathrm{~S}$ may exhibit cyanosis, convulsions, and death [11].

Farm workers are also affected negatively by hydrogen sulfide exposure. Humans can detect a smell like rotten eggs when exposed to 0.1 to $5 \mathrm{ppm}$ of $\mathrm{H}_{2} \mathrm{~S}$, even though these levels are not toxic. Eye and respiratory irritation in humans can occur at $\mathrm{H}_{2} \mathrm{~S}$ levels of $100 \mathrm{ppm}$. High levels of $\mathrm{H}_{2} \mathrm{~S}$, (e.g., 150 to $200 \mathrm{ppm}$ ) cannot be detected by humans due to olfactory paralysis. At levels $>200$ ppm, $\mathrm{H}_{2} \mathrm{~S}$ affect the nervous system and levels $>1,000 \mathrm{ppm}$ result in immediate collapse and respiratory paralysis [12].

There are several possible solutions to mitigate the environmental pollution from animal housing. Excretion of nitrogen and phosphorus can be reduced by formulating diets that improve nutrient digestibility [13]. Feed utilization and dry matter intake can be improved by fine grinding and pelleting, which reduce the size and increase the surface area of grains, thereby increasing the potential for interaction with digestive enzymes [13].

Enzymes can also be used to increase nutrient availability in animal feed. Enzymes can supplement the host's endogenous enzyme production, increasing the availability of nutrients, improving the digestibility of fibrous material, and decreasing any anti-nutritional factors present in feed ingredients [14]. For example, protease can degrade protein sources such as soybean meal and improve protein digestibility [13]. Other indirect contributors to improving swine house environments include antibiotics, probiotics, and organic acids. Low crude protein formulations using synthetic amino acids can also be used to reduce $\mathrm{N}$ excretion.

Probiotics can protect young animals against enteropathogenic disorders and improve growth performance [15]. Studies have shown that probiotics can create a gastrointestinal tract environment that is unfavorable to pathogenic growth [16]. Probiotics can decrease intestinal microbial catabolism and have a protein sparing effect, leading to reduced nitrogen flows [17].

A number of Bacillus strains could be used for feed additive in livestock industry. Bacillus are aerobic or facultative anaerobic, gram-positive, rod-shaped, and spore-forming bacteria. The spore-forming habit of Bacillus is highly beneficial for long term storage without a loss of activity, compared with non-sporeforming bacteria. Spores also have the ability to survive low $\mathrm{pH}$, harsh environments, meaning their probiotic properties can benefit the small intestine [18].

Bacillus in swine can help to improve gut health and immunity for piglets and reduce environmental pollutants such as odor gas emissions from pig manure [19]. Upadhaya et al. [20] proposed that the reduction of fecal $\mathrm{NH}_{3}$ emissions was observed when Bacillus- including feed was supplied to pigs, suggesting the improvement of nutrient digestibility by probiotics. However, Wang et al. [21] reported that it has no influence to enhance nutrient digestibility but indicates the effectiveness for the reduction of slurry $\mathrm{NH}_{3}$ emissions.

The roles of Bacillus in poultry are similar to those in swine. Various effects have been observed in poultry fed with Bacillus, including histological changes in the intestine of broilers, increased villus height and villus height to crypt depth ratio, improved nutrient digestibility and absorption capacity of the small intestine [22], reduced digesta viscosity caused by soluble non-starch polysaccharides (which affect nutrient availability and absorption) [23], improved quality of meat and eggs [24], and reduced $\mathrm{NH}_{3}$ emissions from manure [25].

\section{Effects of Bacillus spp. in swine}

\section{Reduction of ammonia $\left(\mathrm{NH}_{3}\right)$ and hydrogen sulfide $\left(\mathrm{H}_{2} \mathrm{~S}\right)$ excretion}

Ammonia and hydrogen sulfide are negative substances on farm workers as well as animals in swine production and cause environment pollution [26]. Nguyen et al. [27] found that the supplementation of Bacillus-containing feed showed an advantageous effect to decrease $\mathrm{NH}_{3}$ emissions but have no effect on the reduction of other gases $\left(\mathrm{H}_{2} \mathrm{~S}\right.$ and mercaptan). A recent study [27], showed that the addition of the increase in Lactobacillus inhibited pathogenic microorganisms and improved nutrient digestibility, resulting in reduced fecal $\mathrm{NH}_{3}$ emissions.

Growing pigs fed diets with Bacillus licheniformis and Bacillus subtilis for 15 weeks, showed improved performance and reduced gas emissions due to increased fecal Lactobacillus counts and improved utilization of sulfur-containing amino acids [28]. It was concluded that the increase in Lactobacillus reduced intestinal $\mathrm{pH}$ through the production of organic acids, and that the bacitracin (bacteriocin) secreted by B. licheniformis inhibited the microbes that produce urease, thereby reducing $\mathrm{NH}_{3}$ gas emissions. These results are supported by our research data, which showed that pigs fed diets with B. subtilis complex probiotics produced lower $\mathrm{NH}_{3}$ and $\mathrm{H}_{2} \mathrm{~S}$ emissions after a three-week growing period (unpublished data). These results suggest that three weeks of feeding is needed for probiotic adherence in the gut to have positive effects in swine.

According to Balasubramanian et al. [29], when probiotics containing Bacillus coagulans, B. licheniformis, and B. subtilis were fed to growing and finishing pigs over 16 weeks, no reduction in fecal noxious gas $\left(\mathrm{NH}_{3}, \mathrm{H}_{2} \mathrm{~S}\right)$ emissions was observed. Yan et al. [30] found that increased nutrient digestibility reduced the substrate for microbial fermentation in the large intestine, which resulted in a decrease in fecal gas emissions. Chen et al. [31] showed that dietary Bacillus supplementation decreased $\mathrm{NH}_{3}$ emissions, however, other odor substances such as $\mathrm{H}_{2} \mathrm{~S}$ and mercaptan did not decrease. 
Bacillus spp. as probiotics can also affect the production of malodorous substances such as skatole. Skatole is a malodorous compound in meat and fecal that causes an off-flavor, so called "boar taint" [32]. Sheng et al. [33] demonstrated that dietary B. subtilis natto and B. coagulans supplementation decreased the skatole content of meat and feces. Doerner et al. [34] found that the reduced number of Clostridium in the feces of pigs fed Bacillus spp. was consistent with a lower skatole concentration in the meat and feces; Clostridium in feces is involved in the conversion of tryptophan to skatole.

\section{Growth Performance in swine}

Nguyen et al. [27] reported that dietary supplementation with probiotics-based Bacillus in weaning pigs linearly improved average daily gain (ADG) and average daily feed intake (ADFI) on days 0 to 7 of the experiment, as well as ADG and feed conversion ratio (FCR) on days 8 to 21 . According to research by Lan et al. Kim et al. [28], dietary supplementation with B. licheniformis and B. subtilis complex probiotics (Bioplus YC) in growing pigs for 15 weeks resulted in improved growth performance in some periods but there was no significant difference from the control over the study period as a whole. The reasons for improved performance may be explained by changes in intestinal microorganisms and an increase in the secretion of digestive enzymes.

Hu et al. [35] observed that the ADG and FCR of piglets were improved and diarrhea occurrence was reduced when weaning pigs were fed B. subtilis KN-42 for 26 days. Greater bacterial diversity in the intestinal environment indicated an increase in the relative number of Lactobacillus and reduction in the relative number of E. coli in the feces. Wang et al. [21] also reported that ADG tended to increase linearly and ADFI increased as the levels of probiotic (Bioplus $2 \mathrm{~B}^{\circledR}$ ) increased, however, no linear or quadratic effects were observed in FCR.

In growing and finishing pigs, dietary direct-fed microbial (DFM) supplementation has been shown to have negative effects on growth performance. Growing and finishing pigs have better digestibility, improved immunity, and increased resistance to intestinal disorders [36]. Balasubramanian et al. [29] reported that dietary supplementation of three probiotic Bacillus strains (B. coagulans, B. licheniformis, and B. subtilis) did not show a positive effect on the ADG and FCR without affecting ADFI in growing and finishing pigs. Upadhaya et al. [37] reported that there were significantly effective to ADG and ADFI, when two probiotic complexes (B. licheniformis and B. subtilis) was supplied to growing and finishing pigs as feed additive during the experimental period.

According to Patarapreech et al. [38], both types of probiotic additives (Bacillus subtilis + Sanizyme ${ }^{\circledR}$ ) improved the nutrient utilization of feed components [dry matter (DM), crude protein (CP), ether extract (EE), crude fiber (CF), and gross energy (GE)] in the starter and grower periods, as well as growth performance (ADG, ADFI, FCR). Such improvements in nutrient digestibility may be due to the enzymes secreted by Bacillus spp., such as lipase, cellulose, amylase, and protease [39].

The results of probiotic complex supplementation are not consistent. The use of Bacillus-based probiotics in diets fed to finishing pigs did not affect ADG, FCR [40], ADFI, and FCR [31]. Davis et al. [39] also reported that two probiotic Bacillus strains (B. licheniformis and B. subtilis) were ineffective in improving the growth performance in growing and finishing pigs, when they were supplied in feed during test period.

Moreover, Sheng et al. [32] also found that the dietary supplementation of two probiotic complex (B. subtilis natto and B. coagulans) did not show a remarkable improvement of growth performance in growing pigs, but indicate dramatical effects in terms of meat quality, antioxidant function, and the skatole content of meat. The effects of Bacillus-based probiotics are influenced by a variety of factors, (e.g., age of the pigs, diet composition, differences in strains of bacteria, dosage levels, and breeding environment) [41].

\section{Effects of other beneficial microbials}

Growing pigs fed a diet with 10\% palm kernel meal (PKM) and added probiotics (B. subtilis and Saccharomyces cerevisiae), showed a reduction in fecal $\mathrm{NH}_{3}$, total mercaptans, and $\mathrm{H}_{2} \mathrm{~S}$ content [42]; pigs fed a diet without PKM produced less mercaptans than pigs fed diets with PKM. The addition of probiotics to a non-PKM diet had a significant effect on ADG and FCR, but the addition of probiotics to a diet with PKM did not have a positive effect on performance. These results may be due to the presence of nonstarch polysaccharides in PKM creating a viscous environment in the gut.

Chen et al. [43] found the dietary supplementation of three probiotic complex (Lactobacillus acidophilus, S. cerevisiae, and B. subtilis) enhance ADG, when it was provided to the growing pigs for six weeks. In addition, fecal $\mathrm{NH}_{3}-\mathrm{N}$ excretion was reduced when pigs were fed a probiotic complex, however, there was no effect on volatile fatty acid (VFA) production. Chen et al. [31] reported that dietary supplementation probiotics combination (B. subtilis, B. coagulans, and L. acidophilus) in finishing pigs reduced fecal $\mathrm{NH}_{3}-\mathrm{N}$ production and improved ADG, however, there was no effect on ADFI or FCR. In their study, digestibility of $\mathrm{N}$ was not increased, therefore, the reduction in fecal $\mathrm{NH}_{3}-\mathrm{N}$ may not have resulted from nutrient digestibility but rather changes in intestinal microflora.

\section{Effects of Bacillus spp. in poultry}

\section{Reduction in ammonia $\left(\mathrm{NH}_{3}\right)$ and hydrogen sulfide $\left(\mathrm{H}_{2} \mathrm{~S}\right)$ excretion}

In the poultry industry, Bacillus spp. probiotics are widely used. A reduction in $\mathrm{NH}_{3}$ gas emissions from excreta was observed for poultry fed metabolic energy (ME)- and crude protein (CP)reduced diets [44]. Poultry fed probiotic-supplemented diets also showed reduced $\mathrm{NH}_{3}$ gas emissions compared with those fed diets 
without probiotics. Decreasing the CP content of the feed reduces the amount of synthetic amino acids supplied, thereby reducing the amount of $\mathrm{N}$ that is excreted by the poultry [45]. In addition, the feeding of probiotics can lead to increased nutrient utilization and changes in the balance of intestinal microorganisms, which can reduce $\mathrm{NH}_{3}$ gas emissions.

According to research by Jeong et al. and Kim et al. [25], broilers fed a diet supplemented with B. subtilis C-3102 for five weeks, showed a reduction in $\mathrm{NH}_{3}$ due to an increase in the number of Lactobacillus and reduction in the number of pathogenic bacteria. However, there were no effects on $\mathrm{H}_{2} \mathrm{~S}$, mercaptan, or acetic acid production.

Ahmed et al. [46] reported that the supplementation of feed containing Bacillus amyloliquefaciens showed the effect of $\mathrm{NH}_{3}$ reduction in feces during raising term. The observed reduction in $\mathrm{NH}_{3}$ emissions from broiler excreta may be due to increased nutrient utilization and changes in intestinal microbiota. Another reason is that B. amyloliquefaciens reduced the $\mathrm{pH}$ of the feces. A reduced concentration of $\mathrm{E}$. coli and improved utilization of sulfur amino acids in the intestine could reduce the conversion of fecal ammonium to volatile ammonia.

Tang et al. [47] indicated that inclusion of B. amyloliquefaciens product in laying hens reduced $\mathrm{NH}_{3}$ production in a six-week feeding trial; the number of cecal Lactobacillus was increased, but the number of E. coli and Salmonella bacteria and $\mathrm{NH}_{3}$ gas emission was reduced.

\section{Performance in Poultry}

The use of antibiotics in the poultry industry to control pathogenic infections, such as necrotic enteritis, has been banned in some places due to concerns about consumer safety. In such cases, Bacillus spp. have been used to improve performance through positive changes in intestinal microbiota.

Bacillus subtilis was added to a ME- and CP-reduced diet to evaluate the effects of probiotic supplementation related to energy and protein [44]. Poultry fed diets with reduced energy and protein content showed a decreased in ADG and FCR. However, animals fed diets with probiotics showed significant improvements in ADG and FCR in the growing and finishing periods. These performance improvements did not appear immediately; three weeks were required for normal enzyme production that produced effects.

A recent study by Jeong et al. \& Kim et al. [25] found that broilers fed a diet with B. subtilis C-3102 showed improved ADG and FCR, however, there was no effect on meat quality. In this study, Lactobacillus counts in the cecum, ileum, and excreta were significantly increased, and E. coli counts in the cecum and excreta were decreased with dietary B. subtilis supplementation.

Ahmed et al. [46] reported that ADG, ADFI, and FCR were improved when broilers were fed a diet with a B. amyloliquefaciens probiotic; serum IgG and IgA were also increased. Tang et al. [47] reported that laying hens fed a diet with B. amyloliquefaciens commercial product for six weeks had better egg production, eggshell strength, and eggshell thickness than hens that received a non-supplemented diet.

Bacillus amyloliquefaciens has the ability to produce extracellular enzymes, such as cellulose, $\alpha$-amylases, protease, and metalloproteases. Those enzymes can help to increase the efficiency of digestion and absorption of nutrients [48]. Bacillus amyloliquefaciens also produce bacteriocins, such as subtilin, which have antibacterial effects against pathogenic microorganisms [49].

\section{Effects with other beneficial microbial}

Probiotics have been used to reduce $\mathrm{NH}_{3}$ emissions, improve performance, and maintain livestock product safety in the poultry industry, most commonly with a Bacillus spp. complex. In one study, a combination of Pichia guilliermondii, B. subtilis, and Lactobacillus plantarum, at a ratio of $1: 2: 1$, reduced $\mathrm{NH}_{3}$ gas emissions by $46 \%$ in vitro test [50]. This probiotic complex significantly decreased crude protein digestibility, $\mathrm{pH}, \mathrm{NH}_{3}-\mathrm{N}$, urease, and uricase activity. Furthermore, the number of microorganisms responsible for fermenting carbohydrates to produce short chain fatty acids was increased.

\section{Conclusion}

In conclusion, dietary Bacillus spp. probiotic supplementation in monogastric animals can reduce $\mathrm{NH}_{3}$ and $\mathrm{H}_{2} \mathrm{~S}$ production depending on the conditions. In terms of performance, there were various effects of supplementation level, viability, and composition of probiotic species, diet formulation, age of animals, livestock house environment, and so on. Nutrient digestibility can be improved by the enzymes or bacteriocin produced by Bacillus spp.

In addition, supplementation with Bacillus spp. can help reduce fecal odor production, gas emission, and improve the performance of monogastric animals. Additional studies of complex probiotics that satisfy both odor reduction and performance requirements for monogastric animals are recommended.

\section{References}

1. Hays FL, Bianca W (1975) Interrelationships between animals and environment in high-intensity livestock production. Agriculture and Environment 2(4):311-331.

2. Herrero M, Thornton PK (2013) Livestock and global change: Emerging issues for sustainable food systems. PNAS 110(52): 20878-20881.

3. Pelletier N, Tyedmers P (2010) Forecasting potential global environmental costs of livestock production 2000-2050. PNAS 107(43): 18371-18374.

4. Kafle GK, Chen L (2014) Emissions of odor, ammonia, hydrogen sulfide, and volatile organic compounds from shallow-pit pig nursery rooms. Journal of Biosystems Engineering 39(2):76-86.

5. Merchant JA, Ross RF (2002) Iowa concentrated animal feeding operations air quality study, Iowa. 
6. Atia A, Haugen Kozyra K, Amran M (2004) Ammonia and Hydrogen Sulfide Emissions from Livestock Production. Alberta Agriculture Canada.

7. Nahm KH (2003) Evaluation of the nitrogen content in poultry manure. World's Poultry Science Journal 59(1): 77-88.

8. Donham KJ, Knapp LW, Monson R, Gustafson K (1982) Acute toxic exposure to gases from liquid manure. J Occup Med 24(2): 142-145.

9. Donham KJ, Gustafson KE (1982) Human occupational hazards from swine confinement. Annals, American Conference of Governmental Industrial Hygienists 2:137-142.

10. Burns R (2010) Hydrogen Sulfide Spatial Distribution and Worker Exposure in Swine Houses. NPB Reference \# 08-119.

11. OMAFRA Swine Team (2017) Ministry of Agriculture, Food and Rural Affairs, USA.

12. Swine manual. Hydrogen Sulfide Toxicity. Iowa State University, College of Veterinary Medicine, Iowa.

13. Han IK, Lee JH, Piao XS, Li D (2001) Feeding and management system to reduce environmental pollution in swine production. Asian Aust J Anim Sci 14(3): 432-444.

14. Scott TA (1991) Nutritional effects on waste production from monogastrics. Proceedings of Canadian Society of Animal Science Meetings. Chilliwack, B C pp: 35-41.

15. Giesting DW, Easter RA (1985) Response of Starter Pigs to Supplementation of Corn-Soybean Meal Diets with Organic Acids. J Anim Sci 60(5) 1288-1294.

16. Gibson GR, Roberfroid MB (1995) Dietary modulation of the human colonic microbiota: introducing the concept of prebiotics. J. Nutr 125(6): 1401-1412.

17. Vanbelle M, Teller E, and Focant M (1990) Probiotics in animal nutrition: a review. Arch Tierernahr 40(7): 543-567.

18. Cutting SM (2011) Bacillus probiotics. Food Microbiol 28(2): 214-220.

19. Mingmongkolchai S, Panbangred W (2018) Bacillus probiotics: an alternative to antibiotics for livestock production. J Appl Microbiol 124(6): 1334-1346

20. Upadhaya SD, Kim SC, Valientes RA, Kim IH (2015) The Effect of Bacillusbased feed additive on growth performance, nutrient digestibility, fecal gas emission, and pen cleanup characteristics of growing-finishing pigs. Asian Austral J Anim 28(7): 999-1005.

21. Wang Y, Cho JH, Chen JS, Yoo J, Huang HJ, et al. (2009) The effect of probiotic BioPlus $2 \mathrm{~B} \AA$ on growth performance, dry matter and nitrogen digestibility and slurry noxious gas emission in growing pigs. Livest Sci 120(1-2): 35-42.

22. Sen S, Ingale SL, Kim YW, Kim JS, Kim KH, et al. (2012) Effect of supplementation of Bacillus subtilis LS 1-2 to broiler diets on growth performance, nutrient retention, caecal microbiology and small intestinal morphology. Res Vet Sci 93(1): 264-268.

23. Latorre JD, Hernandez X, Bielke LR, Vicente JL, Wolfenden R, et al. (2015) Evaluation of a Bacillus direct-fed microbial candidate on digesta viscosity, bacterial translocation, microbiota composition and bone mineralisation in broiler chickens fed on a rye-based diet. $\mathrm{Br}$ Poult Sci 56(6): 723-732.

24. Yang J, Qian K, Zhang W, Xu Y, Wu Y (2016) Effects of chromiumenriched Bacillus subtilis KT260179 supplementation on chicken growth performance, plasma lipid parameters, tissue chromium levels, cecal bacterial composition and breast meat quality. Lipids Health Dis 15(1): 188

25. Jeong JS, Kim, IH (2014) Effect of Bacillus subtilis C-3102 spores as a probiotic feed supplement on growth performance, noxious gas emission, and intestinal microflora in broilers. Poult Sci 93(12): $3097-$ 3103.

26. Zhang ZF, Kim IH (2014) Effects of multistrain probiotics on growth performance, apparent ileal nutrient digestibility, blood characteristics, cecal microbial shedding, and excreta odour contents in broilers. Poult Sci 93(2):364-370.

27. Nguyen DH, Nyachoti CM, Kim IH (2018) Evaluation of effect of probiotics mixture supplementation on growth performance, nutrient digestibility, faecal bacterial enumeration, and noxious gas emission in weaning pigs. Italian Journal of Animal Science, 18(1): 466-473.

28. Lan R, Kim IH (2018) Effects of Bacillus licheniformis and Bacillus subtilis complex on growth performance and faecal noxious gas emissions in growing-finishing pigs. J Sci Food Agric 99(4):1554-1560.

29. Balasubramanian B, Li T, Kim IH (2016) Effects of supplementing growing-finishing pig diets with Bacillus spp. probiotic on growth performance and meat-carcass grade quality traits. R. Bras. Zootec 45(3): 93-100.

30. Yan L, Kim IH (2011) The apparent total tract digestibility, apparent ileal digestibility and faecal noxious gas content of growing pigs fed probiotics in diets. Wayamba J Anim Sci P122-127.

31. Chen YJ, Min BJ, Cho JH, Kwon OS, Son KS et al. (2006) Effects of dietary Bacillus-based probiotic on growth performance, nutrients digestibility, blood characteristics and fecal noxious gas content in finishing pigs. Asian Australas J Anim Sci 19(4): 587-592.

32. Sheng QK, Zhou KE, H Hu HM, Zhao HB, Zhang Y et al. (2016) Effect of Bacillus subtilis Natto on Meat Quality and Skatole Content in TOPIGS Pigs. Asian Australas J Anim Sci 29(5): 716-721.

33. Strathe AB, Velander IH, Mark T, Kadarmideen HN (2013) Genetic parameters for androstenone and skatole as indicators of boar taint and their relationship to production and litter size traits in Danish Landrace. J Anim Sci 91(6): 2587-2595.

34. Doerner KC, Cook KL, Mason BP (2009) 3-Methylindole production is regulated in Clostridium scatologenes ATCC 25775. Lett Appl Microbiol 48(1): 125-132.

35. Hu Y, Dun Y, Li S, Zhao S, Peng N, et al. (2014) Effects of Bacillus subtilis KN-42 on Growth Performance, Diarrhea and Faecal Bacterial Flora of Weaned Piglets. Asian Australas J Anim Sci 27(8): 1131-1140.

36. Nousiainen J, Setala J (1993) Lactic acid bacteria as animal probiotics Lactic Acid Bacteria. Marcel Dekker Inc, USA.

37. Upadhaya SD, Kim SC, Valientes, Kim IH (2015) The effect of Bacillusbased feed additive on growth performance, nutrient digestibility, fecal gas emission and pen cleanup characteristics of growing-finishing pigs. Asian Aust J Anim Sci 28(7): 999-1005.

38. Patarapreecha P, Jaikan W, Juangsaman A, Khajarern J (2018) Effects of Dietary Bacillus subtilis Supplementation as Probiotics on Growth Performance and Nutrients Digestibility in Fattening Pigs. Pak J Nutr 17(12): 634-640.

39. Davis ME, Parrott T, Brown DC, Rodas BZ, Johnson ZB et al. (2008) Effect of a Bacillus-based direct-fed microbial feed supplement on growth performance and pen cleaning characteristics of growingfinishing pigs. J Anim Sci 86(60): 1459-1467.

40. Munoz D, Lanz A, Lucero P, Soria F, Renteria F et al. (2007) Strategies for enhancing microbiological gut's barrier: BMD and BioPlus 2B. J Anim Sci 85:150.

41. Loh TC, Lee TM, Foo HL, Law FL, Ajion MA (2008) Growth performance and fecal microflora of rats offered metabolites from lactic acid bacteria. J Appl Anim Res 34(1):61-64.

42. Chen W, Zhu XZ, Wang JP, Wang ZX, Huang YQ (2013) Effects of Bacillus subtilis var. natto and Saccharomyces cerevisiae fermented liquid feed 
on growth performance, relative organ weight, intestinal microflora, and organ antioxidant status in Landes geese. J Anim Sci 91(2): 978985.

43. Liu W, Devi S, Park JW, Kim IH (2018) Effects of complex probiotic supplementation in growing pig diets with and without palm kernel expellers on growth performance, nutrient digestibility, blood parameters, fecal microbial shedding and noxious gas emission. Anim Sci J 89(3): 552-560.

44. Upadhaya SD, Rudeaux F, Kim IH (2019) Effects of inclusion of Bacillus subtilis (Gallipro) to energy- and protein-reduced diet on growth performance, nutrient digestibility, and meat quality and gas emission in broilers. Poult Sci 98(5):2169-2178.

45. Ferguson NS, Gates RS, Taraba JL, Cantor AH, Pescatore AJ et al. (1998) The effect of dietary crude protein on growth, ammonia concentration, and litter composition in broilers. Poult Sci 77(10):1481-1487.

46. Ahmed ST, Islam MM, Mun HS, Sim HJ, Kim YJ et al. (2014) Effects of Bacillus amyloliquefaciens as a probiotic strain on growth performance, cecal microflora, and fecal noxious gas emissions of broiler chickens. Poult Sci 93(8): 1963-1971.

47. Tang RY, Wu ZL, Wang GZ, Liu WC (2018) The effect of Bacillus amyloliquefaciens on productive performance of laying hens. Italian Journal of Animal Science 17(2): 436-441.

48. Lee Y, Kim B, Lee B, Jo K, Lee N et al. (2008) Purification and characterization of cellulase produced by Bacillus amyoliquefaciens DL-3 utilizing rice hull. Bioresour Technol 99(2): 378-386.

49. Lisboa MP, Bonatto D, Bizani D, Henriques JA, Brandelli A (2010) Characterization of a bacteriocin-like substance produced by Bacillus amyloliquefaciens isolated from the Brazilian Atlantic forest. Int Microbiol 9(2): 111-118.

50. Mi J, Chen X, Liao X (2019) Screening of single or combined administration of 9 probiotics to reduce ammonia emissions from laying hens. Poult Sci 98(9):3977-3988.

\section{Your next submission with Juniper Publishers will reach you the below assets}

- Quality Editorial service

- Swift Peer Review

- Reprints availability

- E-prints Service

- Manuscript Podcast for convenient understanding

- Global attainment for your research

- Manuscript accessibility in different formats ( Pdf, E-pub, Full Text, Audio)

- Unceasing customer service

Track the below URL for one-step submission https://juniperpublishers.com/online-submission.php 